\title{
Inoculation with the endophytic bacterium Herbaspirillum seropedicae promotes growth, nutrient uptake and photosynthetic efficiency in rice
}

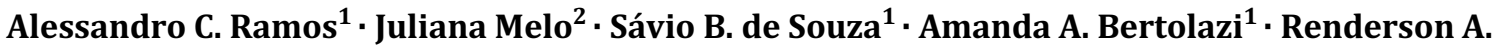 \\ Silva $^{1}$ - Weverton P. Rodrigues ${ }^{3}$ - Eliemar Campostrini ${ }^{3}$ - Fábio L. Olivares ${ }^{4}$ - Frederico J. Eutrópio ${ }^{1}$. \\ Cristina $\mathrm{Cruz}^{2} \cdot$ Teresa Dias $^{2}$ \\ 1 - Environmental Microbiology and Biotechnology Lab; Universidade Vila Velha (UVV), Vila Velha, ES, \\ Brazil
}

2 - Centre for Ecology, Evolution and Environmental Changes, Faculdade de Ciências, Universidade de Lisboa, Lisboa, Portugal

3- Plant physiology lab, Universidade estadual do Norte Fluminense (UENF), Campos dos Goytacazes, RJ, Brazil

4 - Cell Tissue and Biology Lab, Universidade Estadual do Norte Fluminense (UENF), Campos dos Goytacazes, RJ, Brazil

\begin{abstract}
Main conclusion Higher vacuolar proton pump activity may increase plant energy and nutrient use efficiency and provide the nexus between plant inoculation with Herbaspirillum seropedicae and growth promotion.
\end{abstract}

\begin{abstract}
Global change and growing human population are exhausting arable land and resources, including water and ferti- lizers. We present inoculation with the endophytic plant-growth promoting bacterium (PGPB) Herbaspirillum seropedicae as a strategy for promoting growth, nutrient uptake and photosynthetic efficiency in rice (Oryza sativa L.). Because plant nutrient acquisition is coordinated with photosynthesis and the plant carbon status, we hypothesize that inoculation with $H$. seropedicae will stimulate proton $\left(\mathrm{H}^{+}\right)$pumps, increasing plant growth nutrient uptake and photosynthetic efficiency at low nutrient levels. Plants were inoculated and grown in pots with sterile soil for 90 days. Herbaspirillum seropedicae endophytic colonization was successful and, as hypothesized, inoculation (1) stimulated root vacuolar $\mathrm{H}^{+}$pumps (vacuolar $\mathrm{H}^{+}$-ATPase and vacuolar $\mathrm{H}^{+}$-PPase), and (2) increased plant growth, nutrient contents and photosynthetic efficiency. The results showed that inoculation with the endophytic bacterium $H$. seropedicae can promote plant growth, nutrient uptake and photosynthetic efficiency, which will likely result in a more efficient use of resources (nutrients and water) and higher production of nutrient-rich food at reduced economic and environmental costs.
\end{abstract}

Keywords: Endophytic plant-growth promoting bacteria; Nutrients; Photosynthesis; Rice plants; Vacuolar proton pumps

\section{Introduction}

Rice (Oryza sativa L.) is the most important crop worldwide and a primary food source for more than half of humanity. However, to meet the demands of the growing human popu- lation, the world rice production has to increase $25 \%$ over the next 2 decades (Chen et al. 2017). So far, production has been increased by: (1) increasing the farming area, which is no longer sustainable and, therefore, not recommended under the United Nations 'zero net land degradation' goal (https://sustainabledevelopment.un.org); (2) using more productive varieties, including genetically modified rice varieties; and (3) using larger amounts of chemical 
fertiliz- ers, which creates serious environmental and health issues (Sutton et al. 2011). Arable land and resources are being exhausted (Maurino and Weber 2013), and the urgency for more sustainable agricultural practices generating higher crop yields is consensual (Dias et al. 2015). One important approach is to implement or revitalize eco-friendly technolo- gies, such as inoculating crops with plantgrowth promoting bacteria (PGPB), which improve crop production through synthesis of growth promoting substances, increased nutri- ent availability and stimulation of hormone production and plant defence (Cocking 2003; Bhattacharyya and Jha 2012).

Because nitrogen $(\mathrm{N})$ is the main limiting nutrient to cereal production (Ladha and Reddy 2003), rice and other non-legume crops (e.g., maize, wheat) have been inoculated with non-rhizobial diazotrophic PGPB (e.g., Azospirillum brasilense, Gluconacetobacter diazotrophicus, Herbaspiril- lum seropedicae). These bacteria colonize roots endophyti- cally (James et al. 2002) and fix and provide $\mathrm{N}$ to the host plant, increasing crop productivity and quality (Cocking 2003), namely higher contents of protein and of 'digestible' nutrients (Skonieski et al. 2017). Endophytic PGPB are attracted to carbon-based substances excreted by non- legume roots (e.g., rice), and after they attached to the root surface, they initiate the endophytic colonization from newly emerged lateral roots. As in the legume-rhizobial symbiosis, chemical communication between the host plant and the bac- teria also occurs (Monteiro et al. 2012). Besides $\mathrm{N}$ enhance- ment, phosphate solubilization and/or phytohormone pro- duction can also be improved through PGPB inoculation (Araujo et al. 2013; Baldani et al. 2000) as observed for rice (greenhouse trialGyaneshwar et al. 2002), maize (green- house and field trials-Canellas et al. 2013) and sugarcane (greenhouse trial-Aguiar et al. 2016) following inoculation with the PGPB H. seropedicae.

Several mechanisms may be involved in plant growth pro- motion by PGPB. The interactions between $A$. brasilense and soybean and cowpea plants involve increased proton $\left(\mathrm{H}^{+}\right)$efflux at the root surface (Bashan et al. 1992), showing the importance of cell membranes as reliable sensors of bac- terial presence and mediators of bacterial effects on plants. Three types of $\mathrm{H}^{+}$pumps (plasma membrane $\mathrm{H}^{+}$-ATPase, vacuolar $\mathrm{H}^{+}$-ATPase and vacuolar $\mathrm{H}^{+}$-PPase) are responsi- ble for $\mathrm{H}^{+}$efflux into the vacuole or apoplastic space, which generates the $\mathrm{H}^{+}$electrochemical gradient involved in plant cellular nutrition and growth (Felle 2001; Netting 2002; Gao et al. 2004; Shavrukov and Hirai 2016). The plant vacuole builds up cellular turgor and is actively involved in cellular responses to different stimuli. Furthermore, solute uptake into or release out of the vacuole allows cytosolic metabo- lite levels to adapt to changing physiological requirements and specific cellular demands. Solute transport through the vacuolar membrane is, therefore, tightly regulated (Neu- haus and Trentmann 2014), also by vacuolar $\mathrm{H}^{+}$pumps. Indeed, genetic engineering approaches targeting increased $\mathrm{H}^{+}$influx into the vacuole (transgenic overexpression of vacuolar $\mathrm{H}^{+}$-PPase in Arabidopsis thaliana, tomato and rice plants) have been shown to generate higher crop yields (PaezValencia et al. 2013).

Herbaspirillum seropedicae was originally thought to be a new Azospirillum species (James and Olivares 1998). The similarity between Herbaspirillum and Azospirillum made further isolation and work on the former somewhat difficult, until Baldani et al. (1992) developed a new semi- solid malate medium (JNFb medium) that allowed to more easily differentiate the two. As already mentioned, A. bra- silense colonization increases root $\mathrm{H}^{+}$efflux (Bashan et al. 1992). Our aim was, therefore, to test if inoculation with $H$. seropedicae would also stimulate $\mathrm{H}^{+}$pumps, especially at the vacuole, and thus promote growth, nutrient uptake and photosynthetic efficiency in rice plants growing at low nutrient levels.

\section{Materials and methods}

\section{Experimental design}

Our experimental design consisted of one factor, H. sero- pedicae inoculation, resulting in two treatments (non-inoc- ulated-control; and inoculated) with five replicates (pots) per treatment. Herbaspirillum seropedicae strain HRC54, originally isolated from sugarcane roots, has been exten- sively tested on several crops (Olivares et al. 2017). The inoculum was grown at $28^{\circ} \mathrm{C}$ for $36 \mathrm{~h}$ at $150 \mathrm{rpm}$ in JNFb liquid medium (Baldani et al. 1992).

Oryza sativa seeds (kindly provided by Prof. Roberto Gaxiola, Arizona University, USA) were surface sterilized with $70 \%$ ethanol for $3 \mathrm{~min}$, followed by $2 \%$ sodium hypochlorite $(\mathrm{v} / \mathrm{v})$ for $5 \mathrm{~min}$, rinsed five times 
with sterile water, sown on $1 \mathrm{~L}$ pots filled with autoclaved sand, and placed in a growth chamber $116 / 8 \mathrm{~h}$ light/dark; $25 / 20{ }^{\circ} \mathrm{C}$ day/ night; $350 \mu \mathrm{mol} \mathrm{m}^{-2} \mathrm{~s}^{-1}$ ). After 15 days, seedlings were transferred to $1 \mathrm{~L}$ pots (four seedlings per pot) filled with autoclaved sand and a red-yellow oxisol (3:1), and inocu- lated. Half of the plants were inoculated with a living H. seropedicae suspension $\left(10^{9}\right.$ cells $\left.\mathrm{mL}^{-1}\right)$, added directly onto the root system (Baldotto et al. 2011), and the other half with the same but autoclaved suspension (control plants). After 30 days, H. seropedicae was re-inoculated (Rakiami et al. 2019). All plants were watered twice a week with $50 \mathrm{~mL}$ of $1 / 4$ strength modified Clark solution (Clark 1975), establish- ing nutrient limitation, and twice a week with $50 \mathrm{~mL}$ of tap water, in alternating days. Because plant growth promotion can only be observed at later stages of plant-bacterium inter- action (de Souza et al. 2016), plants were grown for 90 days (following the first inoculation), in a growth chamber under the same conditions as described for germination. Pots were randomized once a week.

\section{Harvest and analysis}

The effect of $H$. seropedicae inoculation on rice photosyn- thetic efficiency was analysed immediately before harvest- ing. Net photosynthetic rate $(A)$, stomatal conductance $\left(\mathrm{g}_{\mathrm{s}}\right)$ and intracellular $\mathrm{CO}_{2}$ concentration (Ci) were measured in young fully developed leaves (second or third leaf) in four plants per treatment (from different pots), between 8:00 and 10:00 h using a LI-6200 portable photosynthesis system (LI- COR, Lincoln, NE, USA) with a $6 \mathrm{~cm}^{2}$ leaf chamber. Air temperature inside the chamber was set at $25^{\circ} \mathrm{C}$, and $\mathrm{CO}_{2}$ concentration was kept at 390 ppm (ambient $\mathrm{CO}_{2}$ levels) using a $\mathrm{CO}_{2}$ injector system (LI-COR, Lincoln, NE, USA). Photosynthetic photon flux intensity was $850 \mu \mathrm{mol} \mathrm{m}^{-2} \mathrm{~s}^{-1}$, provided by a red/blue LED light source (6400-02B). $\mathrm{Ci}$ and $\mathrm{g}_{\mathrm{s}}$ were measured at the same time as $\mathrm{A}$, and $\mathrm{A} / \mathrm{Ci}$ (instanta- neous carboxylation efficiency) was calculated.

Plants were harvested 105 days after sowing, and sepa- rated into roots and shoots. The effect of $H$. seropedicae inoculation on rice growth efficiency was analysed by meas- uring shoot length, biomass and stem diameter. The effect of $H$. seropedicae inoculation on rice nutrient uptake was analysed by quantifying shoot concentrations of $\mathrm{P}, \mathrm{K}, \mathrm{Ca}, \mathrm{Mg}, \mathrm{S}, \mathrm{Fe}, \mathrm{Zn}, \mathrm{Mn}, \mathrm{Cu}$ and $\mathrm{B}$. Shoots were dried at $60^{\circ} \mathrm{C}$ until constant weight was achieved, digested with $\mathrm{HNO}_{3}$ (Merck) and $\mathrm{H}_{2} \mathrm{O}_{2}$ (Merck) in an open digestion system (Peters 2005), and analysed by inductively coupled plasma optical emission spectrometry (ICP-OES), with plasma flow rate of $8.0 \mathrm{~L} \mathrm{~min}^{-1}$, auxiliary gas flow rate of $0.70 \mathrm{~L} \mathrm{~min}^{-1}$ and carrier gas flow rate of $0.55 \mathrm{~L} \mathrm{~min}^{-1}$. $\mathrm{N}$ was quantified using the Nessler method (Jackson 1965) as described in the Handbook of Soil and Plant Analysis (Kalra 1997)

Natural

ATP- and $\mathrm{PP}_{\mathrm{i}}$-dependent $\mathrm{H}^{+}$transport across membranes were measured as the initial fluorescence quenching rate of 9-amino-6-chloro-2-methoxyacridine (ACMA) at $25{ }^{\circ} \mathrm{C}$, using a fluorimeter (model F3010, Hitachi, Tokyo), accord- ing to Façanha and de Meis (1998).

\section{Calculations and statistics}

Nutrient contents were calculated using shoot nutrient con- centrations and biomass values. The effect of H. seropedicae inoculation was calculated as follows:

Inoculation effect $(\%)=\left(\right.$ Parameter $_{\text {inoculated }}-$ Average parameter $\left.{ }_{\text {non-inoculated }}\right) /$ Average parameter ${ }_{\text {non- }}$ inoculated $\times 100$.

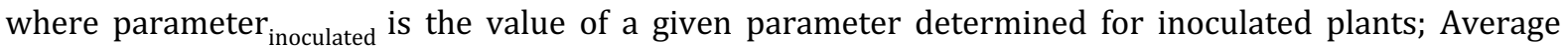
parameter $r_{\text {non-inoculated }}$ is the average value for the same parameter determined for non-inoculated plants. Means were compared using the Student's $t$ test, at $p \leq 0.05$. In all cases, preliminary analyses were performed to ensure no violation of statistical assumptions (including the Levene test for equality of variances). All statistical analyses were performed using the GraphPad Prism 7.0 software. 


\section{Results}

Endophytic colonization of rice roots by the PGPB H. sero- pedicae and lateral root proliferation were observed in all inoculated plants (data not shown). Inoculating rice plants with $H$. seropedicae increased plant growth (Fig. 1), nutri- ent contents (Table 1), and photosynthetic (Fig. 2) and $\mathrm{H}^{+}$-pumping (Fig. 3) activity. Inoculated plants grew more than non-inoculated plants: they were $30 \%$ taller, presented a $70 \%$ wider diameter and accumulated 190\% more bio- mass than non-inoculated plants (Fig. 1). Shoot macro and micronutrient contents were also much higher for inocu- lated than for non-inoculated plants, except for Mg, which was higher for non-inoculated plants (Table 1). Only non- inoculated plants showed paleyellow leaves, especially older ones, indicating nitrogen deficiency (data not shown). Herbaspirillum seropedicae inoculation resulted in ${ }^{15} \mathrm{~N}$ enrichment $\left(\partial^{15} \mathrm{~N}=5.7 \pm 0.5\right.$; Table 1$)$ of inoculated plants, contrasting with a ${ }^{15} \mathrm{~N}$ impoverishment $\left(\partial^{15} \mathrm{~N}=-2.7 \pm 0.3\right)$ in non-inoculated plants. The $\partial^{15} \mathrm{~N}$ values for inoculated plants were closer to those for the soil $\left(\partial^{15} \mathrm{~N}\right.$ soil $\left.=7.9 \pm 0.1\right)$, whereas the $\partial^{15} \mathrm{~N}$ values for noninoculated plants were closer to those for the nutrient solution $\left(\partial^{15} \mathrm{~N}\right.$ nutrient solution $\left.=-1.7 \pm 0.3\right)$.

Net $\mathrm{CO}_{2}$ assimilation rate $\left(A_{390}\right)$ and instantaneous car- boxylation efficiency $\left(A_{390} / C i\right)$ were $80 \%$ higher for inocu- lated than for non-inoculated plants (Fig. 2). No significant differences were observed in internal $\mathrm{CO}_{2}$ concentration (data not shown), whereas stomatal conductance was lower for inoculated plants $\left(\mathrm{g}_{\mathrm{s}}-\right.$ i.e., $40 \%$ higher resistance to $\mathrm{CO}_{2}$ diffusion across stomata).

Herbaspirillum seropedicae inoculation had no effect on root plasma membrane $\mathrm{H}^{+}$-ATPase (ATP hydrolytic activi- ties or $\mathrm{H}^{+}$transport), but greatly increased the hydrolytic activities and $\mathrm{H}^{+}$transport of vacuolar $\mathrm{H}^{+}$ pumps: a 740\% increase in ATP hydrolytic activity and 430\% increase in $\mathrm{H}^{+}$transport was observed for the vacuolar $\mathrm{H}^{+}$-ATPase and a 3970\% increase in PP hydrolytic activity and $1860 \%$ increase in $\mathrm{H}^{+}$transport for the $\mathrm{H}^{+}$-PPase (Fig. 3).

Natural $15 \mathrm{~N}$ abundance in rice shots, soil and nutriente solution were determined by mass spectrometry (IRMS, Micromass-GV Instruments, UK), using the following equa- tion: $\delta^{15} \mathrm{~N}=(R$ sample $/ R$ standard -1$)$ $\times 1000$, where $R$ is the ${ }^{15} \mathrm{~N} /{ }^{14} \mathrm{~N}$ ratio. The $\mathrm{N}$ standard $\left({ }^{15} \mathrm{~N} /{ }^{14} \mathrm{~N}\right.$ ) was atmospheric $\mathrm{N}$ (air) (Sandberg et al. 2012).

Root endophytic colonization by H. seropedicae was immediately (after harvest using fresh roots) confirmed using fluorescence microscopy (Canellas and Olivares 2017).

The effect of $H$. seropedicae inoculation on rice plant $\mathrm{H}^{+}$pumping efficiency (plasma membrane $\mathrm{H}^{+}$ATPase- EC 3.6.3.6; vacuolar $\mathrm{H}^{+}$-ATPase-EC 3.6.1.3; and vacu- olar $\mathrm{H}^{+}$-PPase-EC 3.6.1.1) was determined in fresh roots. Membrane vesicles were isolated from $10 \mathrm{~g} \mathrm{FW}$ of rice roots as described by Giannini and Briskin (1987), frozen in liquid $\mathrm{N}_{2}$ and stored at $-80^{\circ} \mathrm{C}$ until analysis. Protein concentra- tions were determined using the Bradford method (1976). ATPase and PPase activities were determined colorimetri- cally by measuring $\mathrm{P}_{\mathrm{i}}$ release (Fiske and SubbaRow 1925).

\section{Discussion}

Herbaspirillum seropedicae endophytically colonized rice roots and promoted plant growth by increasing nutrient uptake and photosynthetic capacity. For the first time, we showed the importance of vacuolar proton pump activity as a possible mechanism to explain plant growth promotion by PGPB at an early stage of plant-microbial interaction.

Previous studies have shown that endophytic PGPB pro- vide greater crop enhancement than nonendophytic ones (Cocking 2003; Baldani and Baldani 2005), because they are more efficient colonizers, outcompeting other microorgan- isms (Verma et al. 2004). The observed plant growth stimu- lation by $H$. seropedicae was 15-20\% higher than previously reported for rice (Bhattacharjee et al. 2008). This may be due to the fact that in the present case plants were grown under limiting nutrient availability, and PGPB effects are usually higher under stressful or non-favourable conditions (Fonseca et al. 2017; Dias et al. 2018; Al-Garni et al. 2019). However, growth and nutrient uptake increases similar to those observed are 
not expected under field conditions, since PGPB field trials can have inconsistent effects on plant productivity (Kong et al. 2018; Ji et al. 2019; Timmusk et al. 2017). This is because: (1) PGPB isolated from a given crop may not be equally efficient/beneficial to other crops; and (2) variable biotic and abiotic conditions can affect the suc- cess of plant colonization by PGPB, which is not always stably maintained (Ji et al. 2019). Invasiveness should be considered when assessing the ecological impacts of field PGPB inoculation, especially how the inoculated strains survive or colonize the rhizosphere of host crops, how they interact with the indigenous soil microbiome and function, and how the indigenous soil microbiome responds to them, structurally and functionally (Kong et al. 2018). Few studies have evaluated the effects of bacterial inoculation on plant growth promotion and soil microbial community compo- sition under field conditions (Cipriano et al. 2016). Some studies observed no changes in the rhizosphere microbial

community in response to PGPB inoculation (Armada et al. 2018), whereas others observed changes, although without counterproductive effects (Cipriano et al. 2016). Further studies are, therefore, needed.

All plants were supplied with growth-limiting $\mathrm{N}$ ( $0.39 \mathrm{mmol}$ per week), which is consistent with the paleyellow leaves (especially older leaves) observed in non- inoculated plants. However, inoculated plants showed no visual symptoms of nutrient deficiency, and presented higher growth and nutrient contents. Inoculated plants over- came nutrient limitations through better exploitation of soil resources, at least for $\mathrm{N}$, as indicated by the shoot $\partial^{15} \mathrm{~N}$ : inoculated plants presented shoot $\partial^{15} \mathrm{~N}$ values that were more similar to those for the soil than non-inoculated plants, showing that they used a higher proportion of the soil $\mathrm{N}$ than non-inoculated plants.

Several mechanisms may contribute to more efficient nutrient uptake, namely increased lateral root development. If the effect of $H$. seropedicae inoculation was only due to increased root development, then the increases in nutrient

contents and growth should be proportional and identical for all nutrients. However, this was not the case, as inocu- lated plants were significantly more enriched in phospho- rous, potassium, sulphur and zinc than in other nutrients when compared to non-inoculated plants, showing a putative effect of the bacterial inoculation on plant nutritional bal- ance. The effect on plant nutritional balance could, either alone or together with hormonal changes due to $\mathrm{H}$. sero- pedicae activity, may be responsible for changes in plant physiological activity such as photosynthesis (Peng et al. 2002; Zhou et al. 2006; del Amor and CuadraCrespo 2012; Bhattacharjee et al. 2008; de Souza et al. 2016). During photosynthesis, $\mathrm{CO}_{2}$ moves from the atmosphere to the sub-stomatal chamber ( $C i$ ) through stomata, and from there through the leaf mesophyll to the carboxylation site inside the chloroplast stroma (Flexas et al. 2008). In our study, H. seropedicae inoculation stimulated net carbon assimi- lation and carboxylation efficiency despite lower stomatal conductance and similar $\mathrm{Ci}$ (data not shown). Even though we did not measure mesophyll conductance, $H$. seropedi- cae inoculation may have stimulated the biochemical path- way associated with photosynthetic carbon assimilation, as observed for A. thaliana inoculated with Gluconacetobacter diazotrophicus, another endophytic diazotrophic PGPB (de Souza et al. 2016). Furthermore, by decreasing stomatal con- ductance H. seropedicae inoculation may decrease whole canopy transpiration, which is another advantage, especially considering plant water use efficiency.

In contrast with our results, Canellas et al. (2013) reported higher stomatal conductance in maize plants inoculated with $\mathrm{H}$. seropedicae. However, they associated this to the acti- vation of plasma membrane $\mathrm{H}^{+}-$ ATPase, a $\mathrm{H}^{+}$pump that was not affected by $H$. seropedicae in our study. Because ATPase activity is an energy demanding process, the lack of activation of plasma membrane $\mathrm{H}^{+}$-ATPase by $\mathrm{H}$. sero- pedicae inoculation may be a symptom of sugar deprivation of plant root cells (Ramos et al. 2009). On the other hand, $H$. seropedicae inoculation stimulated vacuolar $\mathrm{H}^{+}$-pumps $\left(\mathrm{V}-\mathrm{H}^{+}\right.$-ATPase and especially $\mathrm{H}^{+}$-PPase), which may be an important part of the plant host response to energy consump- tion by the endophyte, as previously shown for arbuscular mycorrhizal fungi (Ramos et al. 2005). Vacuolar $\mathrm{H}^{+}$-pumps have been shown to replace the pivotal role of plasma mem- brane $\mathrm{H}^{+}$-ATPase under stress conditions (Ramos et al. 2009; Maeshima 2000). Our data showed that the energy backup system represented by vacuolar $\mathrm{H}^{+}$pumps is tightly regulated in roots due to the increased energy demand of 'hosting' the endophytic PGPB and increased lateral root proliferation. In particular, activation of the energy-saving PPi metabolism (vacuolar $\mathrm{H}^{+}$-PPase) in roots is an advan- tage, because it saves ATP that is needed for cells with higher metabolic activity located in physiologically strategic root regions (e.g., elongation zone and root hairs) (Ramos 
et al. 2009). Non-exclusively, higher $\mathrm{H}^{+}$pumping activity would enable greater vacuolar compartmentation of solutes and metabolites (including compounds that could inhibit cytoplasmic enzymes) (Neuhaus and Trentmann 2014; Zhang et al. 2017), increasing vacuolar volume and allowing root cells to grow without de novo production of cytosolic components (Dünser and Kleine-Vehn 2015). It is, there- fore, likely that H. seropedicae changed the abundance of vacuolar $\mathrm{H}^{+}$pumps through differential gene expression and/ or changed their activities due to post-translational modifi- cation or by interacting proteins (Neuhaus and Trentmann 2014).

The observed stimulation of $\mathrm{H}$-PPases, and associ- ated increased growth, nutrient contents and photosynthetic efficiency, was within the range reported for trans- genic overexpression of vacuolar $\mathrm{H}^{+}$-PPases (from either Arabidopsis or Thellungiella halophila) in a variety of agriculturally important crops, including rice, grown under normal or stressful conditions, such as drought, salinity, and nutrient limitation (Gaxiola et al. 2001; Li et al. 2005, 2008, 2010; Yang et al. 2007; Pasapula et al. 2011; Paez-Valencia et al. 2013). Our results showed a similarity between the processes involved in plant growth stimulation by the endophytic bacterium $H$. seropedicae or by genetic modifications. This simple inoculation of the endophytic PGPB $H$. seropedicae can promote growth

and photosynthetic efficiency in rice, which will likely result in a more efficient utilization of resources (nutri- ents and water) and increase production of nutrient-rich food at reduced economic and environmental costs (Paez- Valencia et al. 2013).

Author contribution statement ACR, JM, SBS, CC and TD designed the experiment. JM, SBS and RAS conducted the experiment. FLO confirmed microscopically the endophytic colonization of rice roots by $\mathrm{H}$. seropedicae. WPR and EC conducted the gas exchange measurements. ACR, JM, SBS and AAB extracted the membranes and quantified the proton pumps activity, and quantified the nutrients. SBS and FJE analysed the data. ACR, JM, SBS, CC and TD wrote the manuscript and all co-authors reviewed it.

Acknowledgements This work was supported by Fundação de Amparo à Pesquisa do Estado do Rio de JaneiroFAPERJ (\#E- 26/110.081/2014; \#E-26/111.428/2014; \#E-26/111.458/2014), Con- selho Nacional de Desenvolvimento Científico e Tecnológico (CNPq) (\#475436/2010-5; \#312399/2013-8 Grants), Fundação para a Ciência e a Tecnologia (projects PTDC/AGRO-PRO/115888/2009, PTDC/AGR- PRO/1852/2014 and UIDB/00329/2020, and postdoc grant SFRH/ BPD/85419/2012 to Teresa Dias), and CNPq (Postdoc grant to Juliana Melo). We are grateful to Ana Corrêa for the English proof-reading, and to the Editor and Reviewer for their comments and suggestions, which greatly improved the present paper.

\section{References}

Aguiar NO, Medici LO, Olivares FL, Dobbss LB, Torres-Netto A, Silva SF, Novotny EH, Canellas LP (2016) Metabolic profile and antioxidant responses during drought stress recovery in sugarcane treated with humic acids and endophytic diazo- trophic bacteria. Ann Appl Biol 168(2):203-213. https://doi. org/10.1111/aab.12256

Al-Garni SMS, Khan MMA, Bahieldin A (2019) Plant growth- promoting bacteria and silicon fertilizer enhance plant growth and salinity tolerance in Coriandrum sativum. J Plant Interact 14(1):386-396. https://doi.org/10.1080/17429145.2019.16416 35

Araujo AED, Baldani VLD, Galisa PD, Pereira JA, Baldani JI (2013) Response of traditional upland rice varieties to inoculation with selected diazotrophic bacteria isolated from rice cropped at the Northeast region of Brazil. Appl Soil Ecol 64:49-55. https:// doi.org/10.1016/j.apsoil.2012.10.004

Armada E, Leite MFA, Medina A, Azcon R, Kuramae EE (2018) Native bacteria promote plant growth under drought stress con- dition without impacting the rhizomicrobiome. FEMS Micro- biol Ecol. https://doi.org/10.1093/femsec/fiy092

Baldani JI, Baldani VLD (2005) History on the biological nitro- gen fixation research in graminaceous plants: special emphasis on the Brazilian experience. Anais Da Acad Bras De Ciencias 77(3):549-579. https://doi.org/10.1590/s0001-3765200500 0300014 
Baldani VLD, Baldani JI, Olivares F, Dobereiner J (1992) Identification and ecology of Herbaspirillum seropedicae and the closely related Pseudomonas rubrisub albicans. Symbiosis 13(1-3):65-73

Baldani VLD, Baldani JI, Dobereiner J (2000) Inoculation of rice plants with the endophytic diazotrophs Herbaspirillum serope- dicae and Burkholderia spp. Biol Fertil Soils 30(5-6):485-491

Baldotto LEB, Olivares FL, Bressan-Smith R (2011) Structural interaction between GFP-labeled diazotrophic endophytic bacterium Herbaspirillum seropedicae RAM10 and pineapple plantlets "Vitoria." Braz J Microbiol 42(1):114-125. https://doi. org/10.1590/s1517-83822011000100015

Bashan Y, Alcarazmelendez L, Toledo G (1992) Responses of soy- bean and cowpea root membranes to inoculation with Azospiril- lum brasilense. Symbiosis 13(1-3):217-228

Bhattacharjee RB, Singh A, Mukhopadhyay SN (2008) Use of nitro- gen-fixing bacteria as biofertiliser for nonlegumes: prospects and challenges. Appl Microbiol Biotechnol 80(2):199-209. https://doi.org/10.1007/s00253-008-1567-2

Bhattacharyya PN, Jha DK (2012) Plant growth-promoting rhizobacte- ria (PGPR): emergence in agriculture. World J Microbiol Biotech- nol 28(4):1327-1350. https://doi.org/10.1007/s11274-011-0979-9

Bradford MM (1976) A rapid and sensitive method for the quantita- tion of microgram quantities of protein utilizing the principle of protein-dye binding. Anal Biochem 72(1):248-254

Canellas LP, Olivares FL (2017) Production of border cells and colo- nization of maize root tips by Herbaspirillum seropedicae are modulated by humic acid. Plant Soil 417(1-2):403-413. https ://doi.org/10.1007/s11104017-3267-0

Canellas LP, Balmori DM, Medici LO, Aguiar NO, Campostrini E, Rosa RCC, Facanha AR, Olivares FL (2013) A combination of humic substances and Herbaspirillum seropedicae inocula- tion enhances the growth of maize (Zea mays L.). Plant Soil 366(1-2):119-132. https://doi.org/10.1007/s11104-012-1382-5

Chen RS, Cheng YF, Han SY, Van Handel B, Dong L, Li XM, Xie XQ (2017) Whole genome sequencing and compara- tive transcriptome analysis of a novel seawater adapted, salt- resistant rice cultivar-sea rice 86. BMC Genom. https://doi. org/10.1186/s12864-017-4037-3

Cipriano MAP, Lupatini M, Lopes-Santos L, da Silva MJ, Roesch LFW, Destefano SAL, Freitas SS, Kuramae EE (2016) Lettuce and rhizosphere microbiome responses to growth promoting Pseudomonas species under field conditions. FEMS Microbiol Ecol. https://doi.org/10.1093/femsec/fiw197

Clark RB (1975) Characterization of phosphatase of intact maize roots. J Agric Food Chem 23(3):458-460

Cocking EC (2003) Endophytic colonization of plant roots by nitro- gen-fixing bacteria. Plant Soil 252(1):169-175. https://doi. org/10.1023/a:1024106605806

de Souza A, De Souza SA, De Oliveira MVV, Ferraz TM, Figue- iredo F, Da Silva ND, Rangel PL, Panisset CRS, Olivares FL, Campostrini E, De Souza GA (2016) Endophytic colonization of Arabidopsis thaliana by Gluconacetobacter diazotrophicus and its effect on plant growth promotion, plant physiology, and activation of plant defense. Plant Soil 399(1-2):257-270. https ://doi.org/10.1007/s11104-015-2672-5

del Amor FM, Cuadra-Crespo P (2012) Plant growth-promoting bacteria as a tool to improve salinity tolerance in sweet pepper. Funct Plant Biol 39(1):82-90. https://doi.org/10.1071/fp11173

Dias T, Dukes A, Antunes PM (2015) Accounting for soil biotic effects on soil health and crop productivity in the design of crop rotations. J Sci Food Agric 95(3):447-454. https://doi. org/10.1002/jsfa.6565

Dias T, Correia P, Carvalho L, Melo J, de Varennes A, Cruz C (2018) Arbuscular mycorrhizal fungal species differ in their capacity to overrule the soil's legacy from maize monocropping. Appl Soil Ecol 125:177-183. https://doi.org/10.1016/j.apsoil.2017.12.025 
Dünser K, Kleine-Vehn J (2015) Differential growth regulation in plants-the acid growth balloon theory. Curr Opin Plant Biol 28:55-59. https://doi.org/10.1016/j.pbi.2015.08.009

Façanha AR, de Meis L (1998) Reversibility of $\mathrm{H}^{+}$-ATPase and $\mathrm{H}^{+}$-pyrophosphatase in tonoplast vesicles from maize coleoptiles and seeds. Plant Physiol 116(4):1487-1495

Felle HH (2001) pH: Signal and messenger in plant cells. Plant Biol 3(6):577-591. https://doi.org/10.1055/s-200119372

Fiske C, SubbaRow Y (1925) The colorimetric determination of phos- phorus. J Biol Chem 66:375-400

Flexas J, Ribas-Carbo M, Diaz-Espejo A, Galmes J, Medrano H (2008) Mesophyll conductance to $\mathrm{CO}_{2}$ : current knowledge and future prospects. Plant Cell Environ 31(5):602-621. https://doi.org/10 .1111/j.13653040.2007.01757.x

Fonseca MB, Dias T, Carolino MM, Franca MGC, Cruz C (2017) Belowground microbes mitigate plant-plant competition. Plant Sci 262:175-181. https://doi.org/10.1016/j.plantsci.2017.06.006

Gao DJ, Knight MR, Trewavas AJ, Sattelmacher B, Plieth C (2004) Self-reporting Arabidopsis expressing $\mathrm{pH}$ and $\mathrm{Ca}^{2+}$ indica- tors unveil ion dynamics in the cytoplasm and in the apoplast under abiotic stress. Plant Physiol 134(3):898-908. https://doi. org/10.1104/pp.103.032508

Gaxiola RA, Li JS, Undurraga S, Dang LM, Allen GJ, Alper SL, Fink GR (2001) Drought- and salt-tolerant plants result from overexpression of the AVP1 H+-pump. Proc Natl Acad Sci USA 98(20):11444-11449. https://doi.org/10.1073/pnas.191389398

Giannini JL, Briskin DP (1987) Proton transport in plasma membrane and tonoplast vesicles from red beet (Beta vulgaris L.) storage tissue a comparative study of ion effects on $\Delta \mathrm{pH}$ and $\Delta \Psi$. Plant Physiol 84(3):613-618

Gyaneshwar P, James EK, Reddy PM, Ladha JK (2002) Herbaspiril- lum colonization increases growth and nitrogen accumulation in aluminium-tolerant rice varieties. New Phytol 154(1):131-145.

https://doi.org/10.1046/j.1469-8137.2002.00371.x

Jackson M (1965) Soil chemical analysis, 2nd edn. Prentice Hall, New Jersey

James EK, Olivares FL (1998) Infection and colonization of sugar cane and other graminaceous plants by endophytic diazotrophs. Crit

James EK, Gyaneshwar P, Mathan N, Barraquio QL, Reddy PM, Ian- netta PPM, Olivares FL, Ladha JK (2002) Infection and coloniza- tion of rice seedlings by the plant growth-promoting bacterium Herbaspirillum seropedicae Z67. Mol Plant Microbe Interact 15(9):894-906. https://doi.org/10.1094/mpmi.2002.15.9.894

Ji SH, Kim JS, Lee CH, Seo HS, Chun SC, Oh J, Choi EH, Park G (2019) Enhancement of vitality and activity of a plant growth- promoting bacteria (PGPB) by atmospheric pressure non-thermal plasma. Sci Rep. https://doi.org/10.1038/s41598-018-38026-z

Kalra Y (1997) Handbook of reference methods for plant analysis, 1st edn. CRC Press, Boca Raton

Kong ZY, Hart M, Liu HG (2018) Paving the way from the lab to the field: using synthetic microbial consortia to produce high-quality crops. Front Plant Sci. https://doi.org/10.3389/fpls.2018.01467

Ladha JK, Reddy PM (2003) Nitrogen fixation in rice systems: state of knowledge and future prospects. Plant Soil 252(1):151-167. https ://doi.org/10.1023/a:1024175307238

Li JS, Yang HB, Peer WA, Richter G, Blakeslee J, Bandyopadhyay A, Titapiwantakun B, Undurraga S, Khodakovskaya M, Richards EL, Krizek B, Murphy AS, Gilroy S, Gaxiola R (2005) Arabi- dopsis H+-PPase AVP1 regulates auxinmediated organ develop- ment. Science 310(5745):121-125. https://doi.org/10.1126/scien ce.1115711

Li B, Wei AY, Song CX, Li N, Zhang JR (2008) Heterologous expression of the TsVP gene improves the drought resistance of maize. Plant Biotechnol J 6(2):146-159. https://doi.org/10.111 1/j.1467-7652.2007.00301.x 
Li ZG, Baldwin CM, Hu Q, Liu H, Luo H (2010) Heterologous expression of Arabidopsis H+-pyrophosphatase enhances salt tolerance in transgenic creeping bentgrass (Agrostis stolonifera L.). Plant Cell Environ 33(2):272-289. https://doi.org/10.111 1/j.1365-3040.2009.02080.x

Maeshima M (2000) Vacuolar H+-pyrophosphatase. Biochim Biophys Acta Biomembr 1465(1-2):37-51. https://doi.org/10.1016/s0005 -2736(00)00130-9

Maurino VG, Weber APM (2013) Engineering photosynthesis in plants and synthetic microorganisms. J Exp Bot 64(3):743-751. https:// doi.org/10.1093/jxb/ers263

Monteiro RA, Balsanelli E, Wassem R, Marin AM, Brusamarello-San- tos LCC, Schmidt MA, Tadra-Sfeir MZ, Pankievicz VCS, Cruz LM, Chubatsu LS, Pedrosa FO, Souza EM (2012) Herbaspiril- lum-plant interactions: microscopical, histological and molecular aspects. Plant Soil 356(1-2):175-196. https://doi.org/10.1007/ s11104-0121125-7

Netting AG (2002) pH, abscisic acid and the integration of metabolism in plants under stressed and non-stressed conditions. II. Modifica- tions in modes of metabolism induced by variation in the tension on the water column and by stress. J Exp Bot 53(367):151-173. https://doi.org/10.1093/jexbot/53.367.151

Neuhaus HE, Trentmann O (2014) Regulation of transport processes across the tonoplast. Front Plant Sci. https://doi.org/10.3389/ fpls.2014.00460

Olivares FL, Busato JG, de Paula AM, da Silva LL, Aguiar NO, Canel- las LP (2017) Plant growth promoting bacteria and humic sub- stances: crop promotion and mechanisms of action. Chem Biol Technol Agric 4(1):30-42

Paez-Valencia J, Sanchez-Lares J, Marsh E, Dorneles LT, Santos MP, Sanchez D, Winter A, Murphy S, Cox J, Trzaska M, Metler J, Kozic A, Facanha AR, Schachtman D, Sanchez CA, Gaxiola RA (2013) Enhanced proton translocating pyrophosphatase activity improves nitrogen use efficiency in Romaine Lettuce. Plant Phys- iol 161(3):15571569. https://doi.org/10.1104/pp.112.212852

Pasapula V, Shen GX, Kuppu S, Paez-Valencia J, Mendoza M, Hou P, Chen JA, Qiu XY, Zhu LF, Zhang XL, Auld D, Blumwald E,

Zhang H, Gaxiola R, Payton P (2011) Expression of an Arabidop- sis vacuolar $\mathrm{H}^{+}$-pyrophosphatase gene (AVP1) in cotton improves drought- and salt tolerance and increases fibre yield in the field conditions. Plant Biotechnol J 9(1):88-99. https://doi.org/10.111 1/j.1467-7652.2010.00535.x

Peng SB, Biswas JC, Ladha JK, Gyaneshwar P, Chen YZ (2002) Influ- ence of rhizobial inoculation on photosynthesis and grain yield of rice. Agron J 94(4):925-929

Peters J (2005) Wisconsin procedures for soil testing, plant analysis and feed and forage analysis: plant analysis, 1st edn. College of Agriculture and Life Sciences, Wisconsin

Rakiami A, Bechtaoui N, Tahiri AI, Anli M, Meddich A, Oufdou K (2019) Use of Rhizobacteria and Mycorrhizae Consortium in the open field as a strategy for improving crop nutrition, productivity and soil fertility. Front Microbiol. https://doi.org/10.3389/fmicb .2019.01106

Ramos AC, Martins MA, Façanha AR (2005) ATPase and pyroph- osphatase activities in corn root microsomes colonized with arbuscular mycorrhizal fungi. Revista Bras De Ciencia Do Solo 29(2):207-213

Ramos AC, Martins MA, Okorokova-Façanha AL, Olivares FL, Okorokov LA, Sepúlveda N, Feijó JA, Façanha AR (2009) Arbuscular mycorrhizal fungi induce differential activation of the plasma membrane and vacuolar $\mathrm{H}^{+}$pumps in maize roots. Mycor- rhiza 19(2):69-80. https://doi.org/10.1007/s00572-008-0204-3

Sandberg PA, Loudon JE, Sponheimer M (2012) Stable isotope analy- sis in primatology: a critical review. Am J Primatol 74(11):969- 989. https://doi.org/10.1002/ajp.22053

Shavrukov Y, Hirai Y (2016) Good and bad protons: genetic aspects of acidity stress responses in plants. J Exp Bot 67(1):15-30. https ://doi.org/10.1093/jxb/erv437 
Skonieski FR, Viégas J, Martin TN, Nörnberg JL, Meinerz GR, Tonin TJ, Bernhard P, Frata MT (2017) Effect of seed inoculation with Azospirillum brasilense and nitrogen fertilization rates on maize plant yield and silage quality. Revista Bras Zoot 46(9):722-730. https://doi.org/10.1590/s1806-92902017000900003

Sutton MA, Howard CM, Erisman JW, Billen G, Bleeker A, Grennfelt P, van Grinsven H, Grizzetti B (2011) The European Nitrogen Assessment. Cambridge University Press, Cambridge

Timmusk S, Behers L, Muthoni J, Muraya A, Aronsson AC (2017) Perspectives and challenges of microbial application for crop improvement. Front Plant Sci. https://doi.org/10.3389/ fpls.2017.00049

Verma SC, Singh A, Chowdhury SP, Tripathi AK (2004) Endophytic colonization ability of two deep-water rice endophytes, Pan- toea sp. and Ochrobactrum sp. using green fluorescent protein reporter. Biotechnol Lett 26(5):425-429. https://doi.org/10.1023/ B:BILE.0000018263.94440.ab

Yang H, Knapp J, Koirala P, Rajagopal D, Peer WA, Silbart LK, Mur- phy A, Gaxiola RA (2007) Enhanced phosphorus nutrition in monocots and dicots over-expressing a phosphorus-responsive type IH+-pyrophosphatase. Plant Biotechnol J 5(6):735-745. https://doi.org/10.1111/j.1467-7652.2007.00281.x

Zhang H, Zhao F-G, Tang R-J, Yu Y, Song J, Wang Y, Li L, Luan S (2017) Two tonoplast MATE proteins function as turgor-regulating chloride channels in Arabidopsis. PNAS 114(10):E2036-E2045

Zhou XJ, Liang Y, Chen H, Shen SH, Ding YX (2006) Effects of rhizobia inoculation and nitrogen fertilization on photosynthetic physiology of soybean. Photosynthetica 44(4):530-535. https:// doi.org/10.1007/s11099006-0066-x 
Table

Table1 Effect of $H$. seropedicae inoculation on rice shoot mineral contents and isotopic $\mathrm{N}$ signature $\left(\partial^{15} \mathrm{~N}\right)$

\begin{tabular}{|c|c|c|c|}
\hline & Non-inoculated & Inoculated & Inoculation effect \\
\hline \multicolumn{4}{|c|}{ Macronutrients (mg shoot ${ }^{-1}$ ) } \\
\hline $\mathrm{N}^{*}$ & $15 \pm 1$ & $33 \pm 1$ & $+120 \%$ \\
\hline $\mathrm{P} *$ & $1 \pm 0$ & $6 \pm 1$ & $+350 \%$ \\
\hline $\mathrm{K}^{*}$ & $14 \pm 1$ & $77 \pm 1$ & $+430 \%$ \\
\hline $\mathrm{Ca}^{*}$ & $4 \pm 1$ & $11 \pm 1$ & $+150 \%$ \\
\hline $\mathrm{Mg}^{*}$ & $3 \pm 0$ & $6 \pm 1$ & $+110 \%$ \\
\hline $\mathrm{S}^{*}$ & $2 \pm 0$ & $6 \pm 1$ & $+300 \%$ \\
\hline \multicolumn{4}{|c|}{ Micronutrients $\left(\mu \mathrm{g} \mathrm{shoot}^{-1}\right)$} \\
\hline $\mathrm{Fe}^{*}$ & $323 \pm 12$ & $576 \pm 19$ & $+80 \%$ \\
\hline $\mathrm{B}^{*}$ & $15 \pm 1$ & $50 \pm 2$ & $+230 \%$ \\
\hline $\mathrm{Cu}^{*}$ & $10 \pm 1$ & $39 \pm 0$ & $+280 \%$ \\
\hline $\mathrm{Mn}^{*}$ & $682 \pm 28$ & $465 \pm 17$ & $-30 \%$ \\
\hline Mo* & $0 \pm 0$ & $2 \pm 0$ & $+1020 \%$ \\
\hline $\mathrm{Ni}^{*}$ & $11 \pm 0$ & $50 \pm 1$ & $+340 \%$ \\
\hline $\mathrm{Zn} *$ & $95 \pm 13$ & $3385 \pm 193$ & $+3460 \%$ \\
\hline$\partial^{15} \mathrm{~N}^{*}$ & $-2.7 \pm 0.3$ & $5.7 \pm 0.5$ & $\mathrm{Na}$ \\
\hline
\end{tabular}

Values are means $\pm \mathrm{SE}(n=5)$

na means non applicable

*Mark significant effects at $p \leq 0.05$ 


\section{Figures}

Fig.1 Effect of $H$. seropedicae inoculation on rice growth. Growth was evaluated by determining shoot length (a), stem diameter (b) and biomass (c). Bars are means $\pm \operatorname{SE}(n=5)$

Fig.2 Effect of H. seropedicae inoculation on rice photosynthetic activity. Photosynthetic activity was evaluated by determining a net carbon assimilation at ambiente $\mathrm{CO} 2$ concentrations (A390=, b - Stomatal conductance (gs), and c - carboxylation efficiency (A390/Cix 103) Bars are means § SE $(n=5)$.

Fig. 3 Effect of $\mathrm{H}$. seropedi- cae inoculation on rice root $\mathrm{H}^{+}$-pumping activity. Root $\mathrm{H}^{+}$pumping activity was evaluated by determining the hydrolytic activity ( $\mu \mathrm{mol} \mathrm{P} \mathrm{mg}^{-1}$ root $\min ^{-1}$ ) and pro- ton pumping initial velocity (relative fluorescence units) of $a, b$ plasma membrane $\mathrm{H}^{+}$-ATPase $\left(\mathrm{P}-\mathrm{H}^{+}\right.$-ATPase), c, d vacuolar $\mathrm{H}^{+}$-ATPase $\left(\mathrm{V}-\mathrm{H}^{+}\right.$-ATPase), and e, $\mathrm{f}$ vacuolar $\mathrm{H}^{+}$-pyrophosphatase $\left(\mathrm{H}^{+}\right.$-PPase $)$. Bars are means $\pm \mathrm{SE}(\mathrm{n}=5)$ 
Fig 1
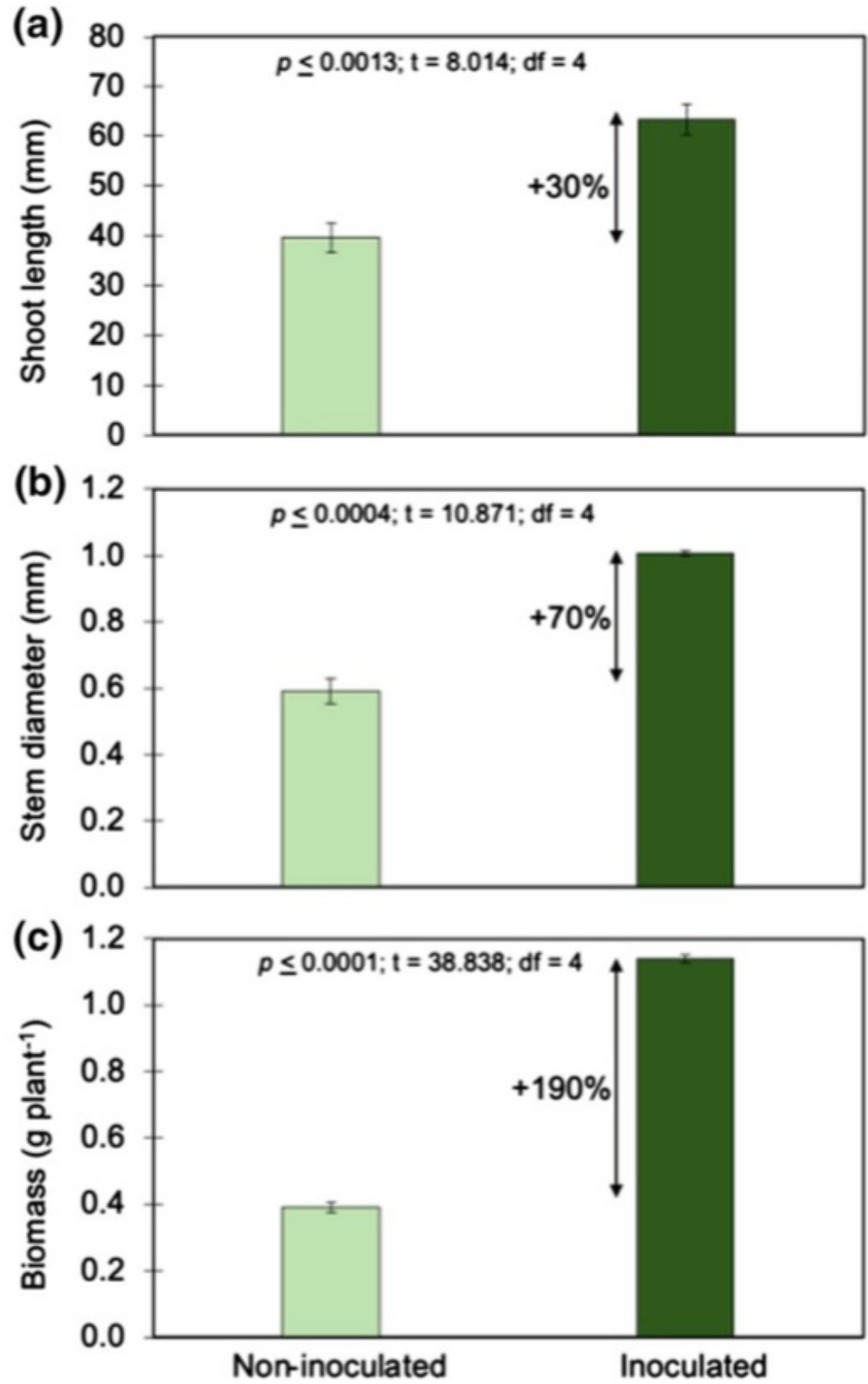
Fig2
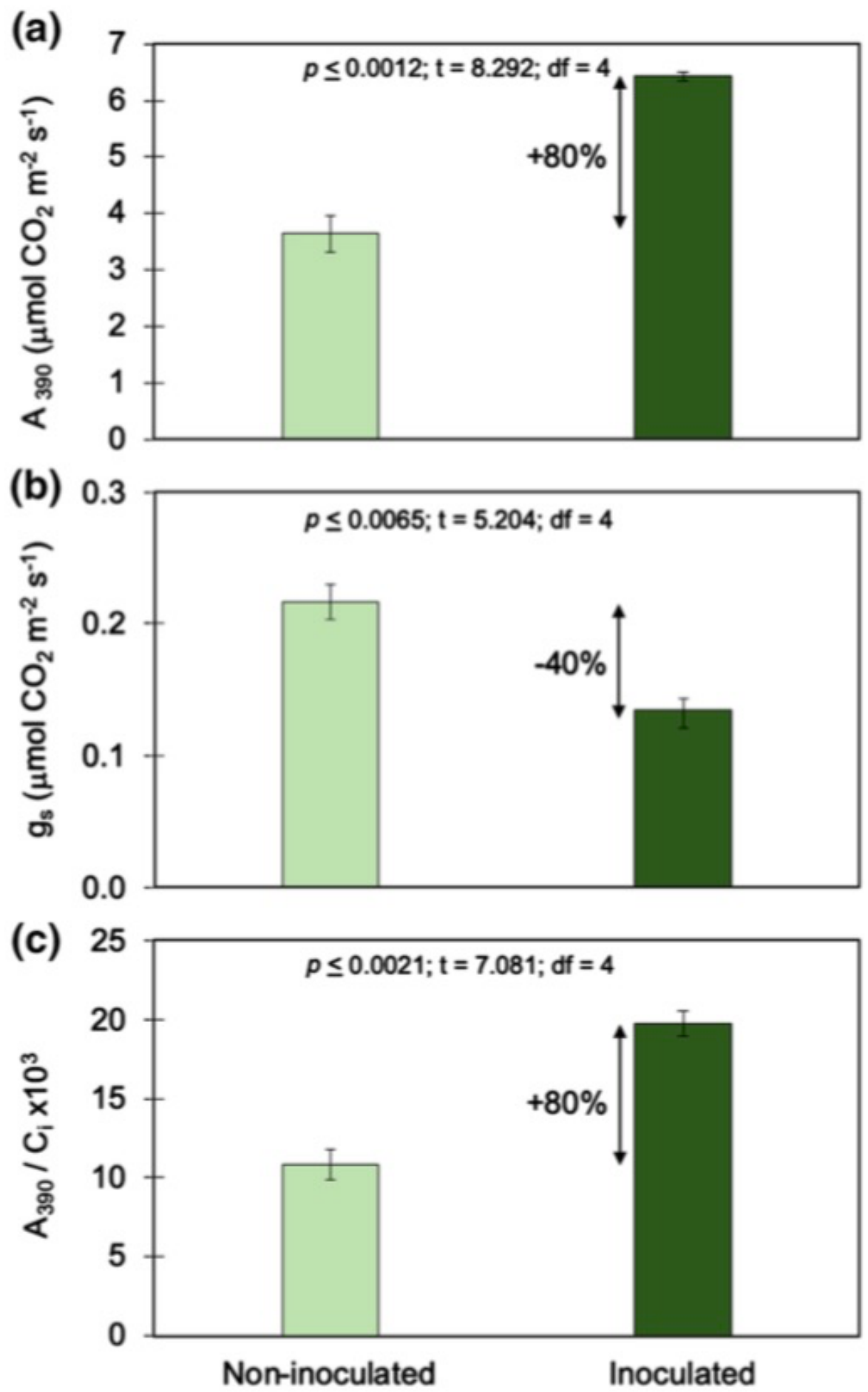
Fig 3
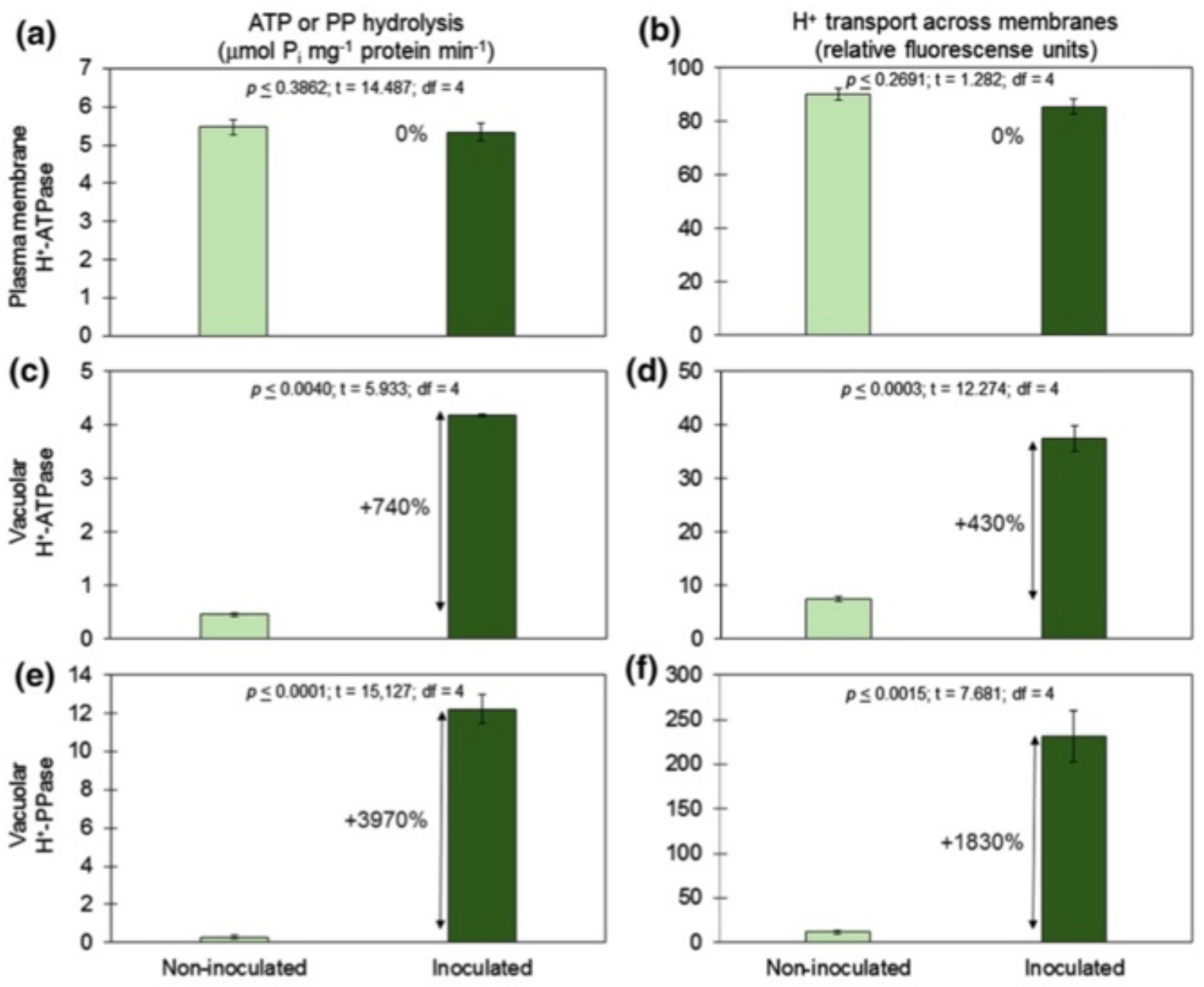